\title{
Production Engineering Competencies in the lndustry 4.0 context: Perspectives on the Brazilian labor market
}

\author{
Christiane Bischof-dos-Santos ${ }^{\mathrm{a*}}$ (D), Elisandreia de Oliveira ${ }^{\mathrm{a}}$ \\ ${ }^{a}$ FAE Centro Universitário, Curitiba, PR, Brasil \\ *christiane.bischof@gmail.com
}

\begin{abstract}
Paper aims: With its focus on Production Engineering, the advent of Industry 4.0 is increasingly changing the way things are done. In order to further the knowledge regarding this context as well as understand to what extent Brazil is prepared for digital transformation, this study has a twofold aim: 1) to provide a comprehensive conceptualization on competencies currently required for production engineers working in Brazilian manufacturing industries and, 2) to verify if these competencies are aligned with those established by the Brazilian Ministry of Education for engineering schools.
\end{abstract}

Originality: Competencies and skills currently required for production engineers have not been described and researched on a comparable in-depth level before.

Research method: Initially, a content analysis was conducted in order to compile the main competencies in Production Engineer job listings. Next, a chi-square analysis was performed to assess relationships between compiled competencies.

Main Findings: The results show that companies are increasingly requiring soft competencies beyond technical expertise, in particular, communication skills.

Implications for theory and practice: Academicians, educators, as well as policy makers and industry leaders can benefit from the information provided in this study.

Keywords

Engineering School. Competencies. Labor Market. Chi-square analysis. Content analysis.

How to cite this article: Bischof-dos-Santos, C., \& Oliveira, E. (2020). Production Engineering Competencies in the Industry 4.0 context: Perspectives on the Brazilian labor market. Production, 30, e20190145. https://doi.org/10.1590/01036513.20190145.

Received: Nov. 26, 2019; Accepted: Oct. 25, 2020.

\section{Introduction}

The Production Engineer, as defined by the Brazilian Ministry of Education (MEC) and CONFEA (Federal Council for Engineering and Agronomy), is a professional who is able to perform a range of activities within industrial manufacturing methods and production lines, and other related services (Conselho Federal de Engenharia e Agronomia, 1973; 1975). These activities include coordination, planning, feasibility studies, technical services, audits, research and teaching, budget preparation, quality monitoring, among others. Notwithstanding this broad characterization, the specific skills and competencies of Production Engineers seemed to be clear.

However, with the emergence of Industry 4.0 and the digitalization involved, these definitions must be revised and updated. As emphasized by Block et al. (2018), historically, as companies' expertise has grown, employees seldom have the necessary competencies to implement digitalization. Murawski \& Bick (2017) add that employees working in knowledge-intensive jobs will need to acquire a certain degree of digital competence to be able to work in the digital age. Therefore, the discussion about employee's qualification is relevant although there are few researches that discuss competencies in Industry 4.0. According to Shamim et al. (2016), there is plenty of literature on Information Systems and Information Technology competencies, but no great amount on Industry 4.0 required competencies. 
The predictions seem scary, but there are some optimistic studies regarding new ways of doing things. According to the 2018 edition of the World Economic Forum's Future of Jobs Report, about 75 million jobs may be displaced in the next five years. In contrast, over the same period, 133 million new jobs may emerge, more adapted to task division between humans and machines. Therefore, schools need to consider including the subject of automation and digital capabilities in their curricula.

However, technological unemployment is still a concern, threatening in particular professionals in the labor market who perform routine and highly standardized tasks. Also, recent graduates, facing the challenges of this new and increasingly digital context, worry about their futures. Harari (2017) recently prophesied that by 2050 a useless class will emerge, made up of professionals who are not skilled for this new brand of work. Thus, Higher Education Institutions must ask themselves if they are properly preparing professionals with the latest required competencies.

In order to tackle this issue, our first aim with this study is to provide a comprehensive conceptualization of competencies currently required for Production Engineers to work in Brazilian manufacturing industries. Next, we intend to compare these competencies with those commonly required for work in an Industry 4.0 context. To achieve this objective, we shall examine job listings published on national online platforms as well as the national regulations applied to the curricula of Brazilian engineering schools.

In short, the research question that will guide this study is: What competencies are needed from Brazilian Production Engineers within the context of a transition to Industry 4.0?

This paper is organized as follows. Following this Introduction, Section 2 describes the Theoretical Background of Industry 4.0 and the necessary competencies. Section 3 presents the Research Design. The results are discussed in Section 4. Finally, Section 5 addresses final considerations, contributions, and limitations of the study.

\section{Theoretical background}

Competencies are key resources in any organizational context. The term competency used in this paper refers to the human capital in the organizations and is constituted from the combination of individuals' workrelated knowledge, skills, and abilities (Cappelli \& Crocker-Hefter, 1996; Nordhaug \& Grenhaug, 1994). An adequate identification and description of specific work-related competencies provides important information in the search for the right employees as well as for measures to be taken within the company. It also provides important guidelines for the development of programs for Higher Education Schools.

With the emergence of Industry 4.0 (i4.0) and the advent of new technologies, a background in information technology and digital systems has received increasing attention from innovative companies. Frey \& Osborne (2013) attracted great public attention when they estimated that 47\% of current US employment is at risk due to computerization. Triggered by such alarming results, other reports dealing with this topic were recently published (Autor, 2015; Freddi, 2018; Organisation for Economic Co-operation and Development, 2016). Despite differing results and conclusions, they all agree that the concept of work will change significantly in the coming decades.

\subsection{Digital competencies}

Individuals, in particular those who work in activities with an intensive focus on knowledge, must continually develop digital competencies in order to cope with new challenges (Murawski \& Bick, 2017). As stated by Vieru et al. (2015), these competencies refer to:

[...] the ability to adopt and use new or existing information technology to analyze, select and critically evaluate digital information in order to investigate and solve work-related problems and develop a collaborative knowledge body while engaging in organizational practices within a specific organizational context. (Vieru et al., 2015, p. 6718).

According to Ahmad et al. (2018), organizations, in particular those operating in fast-changing environments, need to be prepared to deal with challenges related to emerging technologies. The researchers emphasize that it is not one particular task but a process of "transforming". That involves creating and developing distinctive organizational capabilities. Trilling \& Fadel (2009) also state that the appropriate use of digital technologies comprehends communication tools and social networks to access, manage, integrate, evaluate and create information.

The identification of competencies and capabilities in the field of digital manufacturing has been increasingly researched. Ranging from an initial merely technical perspective focused mainly on Internet of Things and Information Systems under i4.0 (as in Debortoli et al., 2014; Ding et al., 2013; Xu et al., 2014) to a more 
comprehensive approach that also acknowledges the importance of the human variable and its capabilities as a decisive influence factor on performance improvement (as in Ahmad et al., 2018; llvonen et al., 2018; Shamim et al., 2016). It should be emphasized that much has been written recently about Industry 4.0. However, there is a lack of studies regarding the development, training, and management of people within the lndustry 4.0 context (Shamim et al., 2017).

Calvani et al. (2008) state that the characteristics of digital competencies are multidimensional as they involve integration between abilities and skills of a cognitive, relational, and social nature; complex since they are not easily quantifiable and assessed; interconnected with key competencies such as problem-solving, logical, and numeracy skills; sensitive to the sociocultural context and to its various settings. Based on these considerations, the researchers suggest a conceptual framework for digital competencies that depicts the coexistence of four dimensions: technological, cognitive, ethical, and the integration of those three. Vieru et al. (2015) adapted this framework to SME (small \& medium enterprises) and addressed the lack of clarity regarding the digital competency concept in this context.

Recently, Murawski \& Bick (2017) assessed digital competencies of the workforce. The researchers found that both career opportunities and potential earnings in the digital age will depend on developing suitable digital competencies. They also point out that digital competencies also require substantial scientific effort to make them applicable, for example in curricula and training designs. More specifically concerning manufacturing maintenance, Bokrantz et al. (2017) studied the effect of digitalized manufacture aiming to contribute to 2030 scenario planning. After listing 34 potential projections, the authors found that

[...] the highly probable future of maintenance organisations is data-driven, fact-based, embedded with smart technology, fuelled by a strong emphasis on continuous development of the workforce, and in accordance to stronger environmental requirements. (Bokrantz et al., 2017, p. 166).

A significant amount of effort has already been put into defining the specific competencies required for each function, for example the competencies recently proposed by the European Committee for Standardization (Comité Européen de Normalisation, 2018) for ICT (Information and Communication Technology) professionals in all industry sectors. The Brazilian government (MEC) also does similar work in defining general competencies for each professional area. These educational guidelines, until recently, have tended to focus on the technical aspects of the profession, neglecting the area of soft skills such as relational capability and communication skills.

In 2018, the World Economic Forum published “The Future of Jobs Report” (World Economic Forum, 2018), which provides a broad analysis of the current world job scenario as well as the far-term horizon. According to the report, technological advancement will reduce the number of workers, but in contrast, it will create a demand for new jobs. The WEF survey projects that, considering a 2022 time horizon, some work tasks will remain human: communicating and interacting, coordinating, developing, managing and advising, as well as reasoning and decision-making. In order to accomplish new tasks and roles, the report suggests skill complementation in what they call "reskilling" by means of training or educational activities.

\subsection{The advent of Industry 4.0 and its impact on Human Resources}

According to Shamim et al. (2016), Industry 4.0 involves smart machines, storage systems, and production facilities. It minimizes human interventions and increases productivity. The authors point out (Shamim et al., 2016, p. 5310) that in Industry 4.0, "[...] organizations will face many economic, social, and technological challenges, which require dynamic capabilities and innovative workforce." As stated by Teece et al. (1997, p. 516), dynamic capabilities involve the integration, building, and reconfiguration of "[...] internal and external competences to address rapidly changing environments". The term "dynamic" refers to competencies' renewal capability in order to continuously respond to the changing environment (Teece et al., 1997; Ambrosini \& Bowman, 2009). In the context of Industry 4.0, the competencies renewal must be driven with a focus on promoting innovation and learning orientation in the organization.

Employees whose goal orientation is learning prefer to engage in challenging tasks, improve themselves continuously, and develop new skill sets. Therefore, individuals are expected to present innovative behavior, such as openness to new experiences

[...] characterized by active imagination, inner feeling attentiveness, variety preferences, intellectual curiosity, creativity, and flexible thinking. (Shamim et al., 2016, p. 5312). 
Graczyk-Kucharska et al. (2018) state that it is important to focus on skills connected with machines while understanding and processing data into information and values. They considered important competencies related to data analysis and 3D designing. Technical knowledge in production companies continues to be a must and should not be neglected. Lastly, the researchers emphasize that soft competencies, such as team management, communication, teamwork, and emotional intelligence, should be increasingly required.

In a much less rigid approach, Ghobakhloo (2018) suggests companies should be free to define their own Industry 4.0 roadmap respecting their idiosyncrasies, based on companies' core competencies, motivations, capabilities, intents, goals, priorities, and budgets. However, he points out that new recruits should be "[...] multi-skilled and flexible enough to adapt to any technology that may emerge as a requirement for Industry 4.0." (Ghobakhloo, 2018, p. 21)

As Industry 4.0 takes shape, indeed, individuals are experiencing an increased complexity in their daily tasks: they are required to be highly flexible and to demonstrate adaptive capabilities in a very dynamic environment (Longo et al., 2017). In this vein, Abele et al. (2017) suggest a "learning factories" approach to develop engineering students. This approach involves the collaboration between academia and industry and is based on the "knowledge triangle": research (knowledge creation), education (knowledge diffusion) and innovation (knowledge application).

\subsection{Production engineering competencies}

Recently, Santos et al. (2017) and Lima et al. (2017) studied the industrial engineering profile considering two categories of competencies: transversal and technical. Transversal competencies (also called soft skills according to Yanaze \& Lopes, 2015) are related to aspects such as relational capabilities, learning, and communication. Technical competencies rely on abilities such as analyzing, designing, planning, and developing (Rouvrais et al., 2006; Santos et al., 2017). Table 1 presents the main transversal and technical competencies considered by Rouvrais et al. in their research.

Table 1. Main competency domains.

\begin{tabular}{ll}
\hline Transversal competencies & Interpersonal communication (group work, creativity) \\
& Learning orientation \\
& Oral and written communication \\
Technical competencies & Project management \\
& Designing \\
Modelling & Developing \\
& Testing, assessing and validating solutions \\
\hline
\end{tabular}

Source: adapted from Rouvrais et al. (2006)

The results from the Santos et al. (2017) study suggest that both transversal and technical competencies are relevant for production engineers. In more detail than Rouvrais et al. (2006), Santos et al. considered 10 technical and 14 transversal competencies for production engineering graduates. Interestingly, these researchers found that the main gaps regarding transversal competencies for engineers are oral and written communication as well as proficiency in a foreign language.

Yanaze \& Lopes (2015) performed a broader study about electrical and computer engineers' competencies. According to their analysis, the labor market requires mainly: 1) communication skills; 2) the ability to work in groups and in a multidisciplinary way; and 3) the capability to solve problems and analyze tasks.

Lima et al. (2017) also identified that technical knowledge alone is not enough for engineers to exercise their profession. The researchers underscore the importance of transversal competencies, and suggest that these skills are not given the appropriate relevance in school curricula.

\subsubsection{Brazilian guidelines for production engineering competencies}

The required competencies for each undergraduate program are based on the National Curriculum Guidelines (DCN). The latest DCN for Engineering courses were published in 2019 and for the first time included competencybased education and action learning. The document points out the difficulties Brazil faces to compete in the international market, evidenced by its decreasing positions in international rankings for Innovation and Intellectual Property (Brasil, 2019a). 
According to the DCN, Engineering Education should aim at developing specific competencies in accordance with the following principles (Brasil, 2019a):

1. Designing and developing engineering solutions, analyzing and understanding users' needs within their context.

11. Analyzing and comprehending physical and chemical data, experimentally verified and validated.

111. Conceiving, designing, and analyzing systems, products (goods and services), components, or processes.

IV. Implementing, supervising and controlling engineering solutions.

V. Communicating effectively in written, oral, and graphic form.

Vl. Working and leading multidisciplinary teams.

Vll. Knowing and ethically using regulations and further regulatory acts while executing engineering functions.

VIII. Developing autonomous learning skills and dealing with complex situations and contexts regarding science and technology advances as well as the challenges of innovation.

The academic quality and performance of undergraduate programs are periodically assessed through evaluation instruments coordinated by the SINAES (National System of Higher Education Evaluation). The instruments utilized to provide quality indicators and conduct program evaluations are the National Examination of Student Performance (ENADE) and in loco assessments, performed by specialized commissions. These tools are developed by INEP - Anisio Teixeira National Institute for Educational Studies and Research. The most recent ENADE for Engineering programs took place in November 2019.

Regarding production engineering, ENADE 2019 aimed to assess whether graduates developed, during the engineering course, the following competencies (Brasil, 2019b):

1. Designing and conducting experiments as well as interpreting outcomes.

11. Designing, managing, and optimizing information and material flows in the production systems, using adequate methods and technologies.

111. Identifying, planning, implementing, controlling, and improving processes and products using adequate tools and techniques.

IV. Improving the relationship between individuals and work environment in production systems.

V. Preparing, implementing, and managing monitoring, controlling, and auditing rules and procedures.

Vl. Predicting and analyzing demands and scenarios in order to assure that products and process planning are suited to organization sustainability.

VIl. Designing models to evaluate and simulate production system performance.

VIII. Developing and implementing technological, managerial, and business model innovation.

Recently, Organisation for Economic Co-operation and Development (2018) published a report criticizing the system used to evaluate Higher Education Institutions in Brazil. According to this report (p.28), the exam to verify school quality- the National Examination of Student Performance (ENADE) has "significant weaknesses", especially regarding required competencies that were considered by analysts to be problematic and unrealistic. According to OECD, specific content in the exam risks undermining the freedom to innovate, since this ends up influencing what is taught. From this perspective, we also intend to verify whether the established competencies for production engineers, which are used to guide the ENADE evaluation, are aligned with labor market demands, as well as the Industry 4.0 context. We have chosen to focus on Production Engineering and Industry 4.0 competencies. In no way is it the intent of this article to discuss or criticize the efficiency of the Brazilian educational system or the current quality of Engineering schools or curricula.

\section{Research design}

This study has a twofold aim: 1) to provide a comprehensive conceptualization of competencies currently in demand for Production Engineers to work in Brazilian manufacturing industries and, 2) to verify whether these competencies are aligned with those established by the Brazilian Ministry of Education for Engineering Schools. 
Content Analysis was used to investigate 152 online published job listings. The categories used to perform this analysis consisted of the competencies mentioned previously in the literature review. Categories, according to Bardin (2011), can be predefined based on the theoretical referential or emerge from the analysis in a deductive approach. In this study, both a priori and a posteriori categories were defined. The a priori categories were based on those by Brill et al. (2006) for effective Project Management, and Graczyk-Kucharska et al. (2018) and Shamim et al. (2016) for Industry 4.0 demands. The competencies required by the Brazilian Ministry of Education underwent recodification. The a posteriori categories came from content analysis of job listings.

To achieve the first aim, job listings published on national online platforms over a three-month period were assessed. Thus, we collected opportunities for production engineers (ranging from "recent graduates" to "experienced/senior" levels) from January to March 2019. Then a content analysis by category was conducted using Atlas.ti QDAS.

In addition, the competencies categorized in the first part of the work were compared to those from INEP and i4.0-demanded competencies using a simple bar chart. INEP and i4.0 competencies were also summarized in nine main categories and underwent the same categorization as revealed by the content analysis. Once categories were all aligned, the procedure allowed the comparison between these qualitative data.

Using the most frequent competencies, we then proceeded to a pair analysis using the chi-square test for independence within variables. This analysis aims to verify it there is any kind of relationship between competencies. The following hypotheses are then proposed:

- $\mathrm{H}_{0}$ : variables are independent or not associated with each other

- $\mathrm{H}_{1}$ : variables are dependent or are associated with each other

With this result, this study aims to promote assertions regarding production engineering competencies currently required in Brazil, as well as to assess alignment with Industry 4.0-demanded competencies.

\section{Results}

Nine categories of required competencies were found, as a result of the literature and regulations review as well as content analysis. Table 2 is a summary of all codifications and recodifications. The column "Determination of category" was included to clarify at what point in the research sequence each category was defined.

The first round of codification was done using mainly i4.0 competencies according to the aforementioned literature. The listings were all analyzed and coded. In general, more than one code (related to competencies)

Table 2. Categories used/defined from Content Analysis.

\begin{tabular}{|c|c|c|}
\hline Categories (Competencies) & Determination of category & Definition used in this study \\
\hline Analytical expertise & A priori & $\begin{array}{l}\text { According to Brill et al. (2006) involves prioritizing, capturing, and using } \\
\text { knowledge, being able to research. }\end{array}$ \\
\hline Autonomy & A priori/a posteriori & $\begin{array}{l}\text { Related to self-driven ways of working, initiative and ability to work } \\
\text { efficiently without direct supervision, and improve themselves continuously } \\
\text { (Shamim et al., 2016) }\end{array}$ \\
\hline Communication skills & A priori/a posteriori & $\begin{array}{l}\text { Involves listening effectively, having strong verbal and written } \\
\text { communication skills (Brill et al., 2006). In our study, proficiency in } \\
\text { different languages was also considered a significant communication skill. }\end{array}$ \\
\hline Creativity & A priori & $\begin{array}{l}\text { As stated in the WEF report, }(2018, \text { p.29), "innovation requires creativity } \\
\text { and alternative thinking to develop new ideas for and answers to work- } \\
\text { related problems". }\end{array}$ \\
\hline Multi-skilled and Flexible & A priori & $\begin{array}{l}\text { Presented in the listings as 'able to work with multidisciplinary scope } \\
\text { of development' and 'successful integration in interdisciplinary and } \\
\text { multicultural teams.' Adaptation to any technology is also a required } \\
\text { competency, as stated by Ghobakhloo (2018). }\end{array}$ \\
\hline Problem-solving expertise & A priori & $\begin{array}{l}\text { Considered by Brill et al. (2006) as the individual's ability to recognize a } \\
\text { problem, manage crises and risk, frame a problem, know the escalation } \\
\text { point, and know how to apply alternate methods. }\end{array}$ \\
\hline Project management skills & A priori & $\begin{array}{l}\text { "The application of knowledge, skills, tools, and techniques to project } \\
\text { activities to meet project requirements" (Englund \& Highlights, 2012) }\end{array}$ \\
\hline Relational capability & A priori & $\begin{array}{l}\text { According to Dyer \& Singh (1998), relational capital refers to mutual trust, } \\
\text { respect, friendship, and high reciprocity among individuals. }\end{array}$ \\
\hline Technical expertise & A posteriori & $\begin{array}{l}\text { According to Santos et al. (2017), technical competencies are related } \\
\text { to different actions such as analysis, design, planning, implementation, } \\
\text { control, and improvement. }\end{array}$ \\
\hline
\end{tabular}


was attributed. It was possible to identify frequently paired competencies in different listings. Chi-square analysis was then applied to verify interdependencies.

Figure 1 shows the distribution of these categories within the three sources of information (Job listings for production engineers in Brazil, Brazilian Ministry of Education - INEP regulations, competencies considered for Industry 4.0).

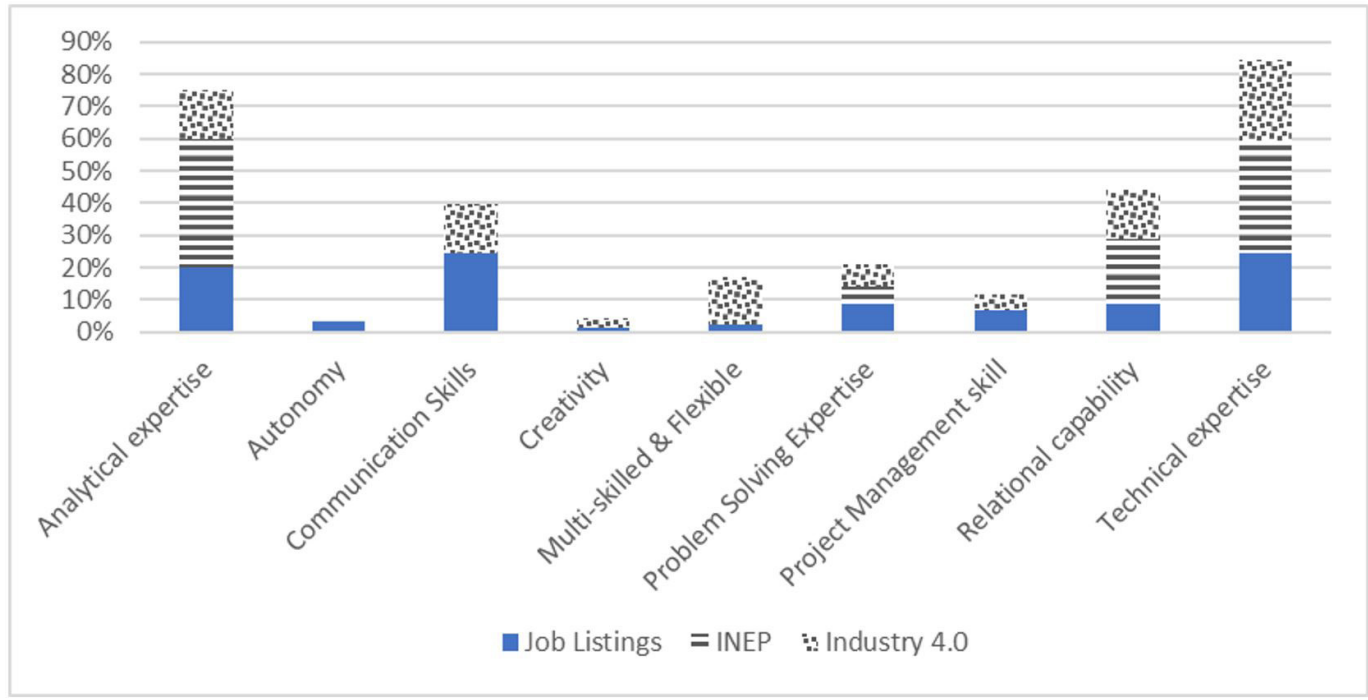

Figure 1. Competency Categories Distribution per demand category.

Analytical expertise competency is frequently in demand from all sources. The recurrent use of the words "analyze", "design", and "interpretation" was found. Technical expertise is understandably in high demand from all three sources as well, considering the utmost importance of technically-skilled professionals.

It is striking that communication skills are the most frequent in the employment listings category. All engineering listings, without exception, require communication skills, mostly the English language. Indeed, Santos et al. (2017) pointed out the relevance knowledge of a foreign language has in an engineer's development. Lima et al. (2017) study also depicts the foreign language as the most important transversal competence demanded by the companies. It appears as an important competency for i4.0 as well, though not as intensively, given the reality of connectivity and networking.

What is also important to highlight is the strong i4.0 emphasis on competencies that are quite underestimated or even neglected by the Brazilian labor market and INEP. They are: multi-skilled and flexible attitude, context knowledge, learning orientation. According to Shamim et al. (2016) and Ghobakhloo (2018), these competencies are very relevant since they encourage employees to adapt to any technology, engage in challenging tasks, improve themselves continuously, and develop new skills. Fortunately, relational capabilities, which were missing from the 2017 document, were included in the latest version of MEC guidelines (Brasil, 2019a).

Autonomy was found only in job listings and refers to the capacity of work without direct supervision (Shamim et al. 2016) using term as "self-driven ways of working" or even "proven ability to work efficiently without direct supervision". Back to the DCN (Brasil, 2019a) we find "autonomous learning skills" related to self-development and learning orientation. The focus of this study is not to define how autonomy should be described, but it is interesting to identify these two different perspectives.

Next, paired competencies were taken in order to test independence between them, by means of a chi-square statistic $(p<0.05)$. The null hypothesis rejection implies that the paired competencies are not independent and there is a relationship between them. Table 3 below shows only paired competencies in which chi-square resulted in a significant $p$-value and, consequently, null hypotheses rejection. For this study, rejection means that both paired competencies tend to be identified together in the same job listing.

Through chi-square statistics, it is possible to observe that the most frequent categories (communication skills and technical expertise) are strongly associated. The increasing demand for communication skills is to be expected based on Graczyk-Kucharska et al. (2018) and the relation with technical skills is probably due to the necessary sharing of technical knowledge in a learning organization scenario. 


\begin{tabular}{lcr}
\hline \multicolumn{1}{c}{ Peer analysis } & Chi-square statistic & p-Value \\
\hline Analytical Expertise x Autonomy & 5.820 & 0.016 \\
Analytical Expertise x Communication skills & 22.530 & 0.001 \\
Analytical Expertise x Problem Solving Expertise & 10.124 & 5.003 \\
Analytical Expertise x Project management & 12.800 & 0.021 \\
Analytical Expertise x Relational Capability & 10.889 & $<.001$ \\
Analytical Expertise x Technical Expertise & 10.124 & 0.001 \\
Autonomy x Communication skills & 5.822 & 0.003 \\
Autonomy x Relational Capability & 34.458 & 0.016 \\
Communication x Technical Expertise & 5.822 \\
Context knowledge x Problem Solving Expertise & 10.124 \\
Problem Solving Expertise x Relational Capability & 5.822 \\
Project Management x Technical Expertise & 7.143 \\
Relational Capability x Technical Expertise & 0.016 \\
\hline
\end{tabular}

Communication skills are also strongly associated with analytical expertise. As with technical expertise, analytical expertise involves gathering information and, most importantly, this information must be correct. It requires listening comprehension as an essential part of good communication. Communication skills are also significantly associated with autonomy, meaning that engineers who aim to improve analysis and autonomy skills must develop good communication. According to lima et al. (2017), communication and the knowledge of a non-native language (mostly English) imply the access to other professionals at different levels as well as working in multicultural teams. The same reasoning can be used to understand why Relational Capability is also associated with Autonomy and Analytical Expertise. The relational capability can be associated to the engagement of employees in teamwork and interaction with work colleagues. Santos et al. (2017) also found that the capability to work in multidisciplinary teams is one of the most important transversal competencies demanded by the engineer's employers.

Another interesting association was revealed between Problem-Solving Expertise and Relational Capability. While Problem Solving involves continuous learning, relational capability fosters knowledge exchange. As Uzzi (1997, p. 47) states, "[...] relational capital involves development of trust, information sharing and joint problem solving". Problem Solving is also correlated to Analytical Expertise which seems quite appropriate since ProblemSolving methodologies involve a strong focus on root-cause analysis.

Technical Expertise is also significantly associated with Analytical Expertise, Project Management, and Relational Capability. This shows that companies are hiring based not only on their technical skill, but also on engineers' know-how for structuring, analyzing, and exchanging technical knowledge.

\section{Final considerations}

It is undeniable that digitalization and Industry 4.0 significantly affect the production engineering professional. Despite the increasing popularity of Industry 4.0, there are still significant doubts regarding its comprehensiveness, expected results, and implementation costs.

The purpose of this article was to identify the competencies needed from Brazilian production engineers in the context of the transition to Industry 4.0. The results show that companies are increasingly requiring soft competencies beyond technical expertise, in particular communication skills. In addition to reading and writing skills, knowledge of a foreign language is part of these communication skills and is intensely required by companies.

Relational capabilities also have an important role in this changing context. Together with communication, relational capabilities are important boosters for knowledge exchange as well as for company innovation. Still, current employees may not have all the competencies needed to operate in a digitized factory. They are, nonetheless, well experienced regarding company procedures, norms, and workplace culture. Even if the transition to Industry 4.0 requires a complete overhaul of a company's operations and manufacturing processes, the existing employees have a significant advantage, and the decision should be to train them in the necessary skills (reskilling) and professionally adapt them to the upcoming technologies and procedures.

As limitations to the study, we can point out that some of the job advertisements are not detailed focusing only on the main technical expertise needed (e.g. experience in grinding processes). Other limitation is that we 
considered only a few job platforms and we did not check the effective impact of these platforms in Brazilian labor market, in particular, for engineers.

This study considered job listings from January to March 2019. Further studies should be conducted considering more recent listings. A study focusing other engineering areas is also recommended. In addition, it would also be interesting to study the effect of the COVID pandemic on labor system.

Other suggestion for further studies refers to the competencies that were found only in the job listings (market demands) and there is no mention neither in MEC directives nor in i4.0 digital capabilities. As an example, we can mention autonomy, in the sense of self-driven work, without the need of supervision. A study to verify if autonomy is a behavioral characteristic, if it is only related to experience or even if it can be developed would be quite interesting.

This analysis focused on the multidimensional nature of Industry 4.0 and related digital competencies is timely and welcome. Policymakers, industry leaders, as well as academicians and educators can benefit from the information provided in this study.

\section{References}

Abele, E., Chryssolouris, G., Sihn, W., Metternich, J., ElMaraghy, H., Seliger, G., Sivard, G., ElMaraghy, W., Hummel, V., Tisch, M., \& Seifermann, S. (2017). Learning factories for future oriented research and education in manufacturing. CIRP Annals - Manufacturing Technology, 66(2), 803-826. http://dx.doi.org/10.1016/j.cirp.2017.05.005.

Ahmad, M., Papert, M., \& Pflaum, A. (2018). Dynamic Capabilities related Implementation Skills for Internet of Things Solutions in the Digital Economy. In 51st Hawaii International Conference on System Sciences, 9 (pp. 3996-4005). Honolulu, HI: HICSS. http:// dx.doi.org/10.24251/HICSS.2018.502

Ambrosini, V., \& Bowman, C. (2009). What are dynamic capabilities and are they a useful construct in strategic management? International Journal of Management Reviews, 11(1), 29-49. http://dx.doi.org/10.1111/j.1468-2370.2008.00251.x.

Autor, D. H. (2015). Why are there still so many jobs. The Journal of Economic Perspectives, 29(3), 3-30. http://dx.doi.org/10.1257/ jep.29.3.3.

Bardin, L. (2011). Análise de Conteúdo. São Paulo: Edições 70.

Block, C., Kreimeier, D., \& Kuhlenkötter, B. (2018). Holistic approach for teaching IT skills in a production environment. Procedia Manufacturing, 23(2017), 57-62. http://dx.doi.org/10.1016/j.promfg.2018.03.161.

Bokrantz, J., Skoogh, A., Berlin, C., \& Stahre, J. (2017). Maintenance in digitalized manufacturing: Delphi-based scenarios for 2030. International Journal of Production Economics, 191, 154-169. http://dx.doi.org/10.1016/j.jpe.2017.06.010.

Brasil, Ministério da Educação. Conselho Nacional de Educação. (2019a, April 23). Diretrizes Curriculares Nacionais do Curso de Graduação em Engenharia. Decisão CNE/CES 1/2019. Diário Oficial da República Federativa do Brasil, Seção 1.

Brasil, Ministério da Educação. (2019b, June 3). Dispõe sobre o componente específico da área de Engenharia de Produção do Enade 2019 (Portaria $n^{\circ}$ 499, de 31 de maio de 2019). Diário Oficial da República Federativa do Brasil, Seção 1

Brill, J. M., Bishop, M. J., \& Walker, A. E. (2006). The competencies and characteristic required of an effective project manager: a web-based Delphi study. Educational Technology Research and Development, 54(2), 115-140. http://dx.doi.org/10.1007/s11423-006-8251-y.

Calvani, A., Cartelli, A., Fini, A., \& Ranieri, M. (2008). Models and Instruments for Assessing Digital Competence at School. Journal of E-Learning and KnowledgeSociety, 4(3), 183-193. http://dx.doi.org/10.20368/1971-8829/288.

Cappelli, P., \& Crocker-Hefter, A. (1996). Distinctive human resources are firms' core competencies. Organizational Dynamics, 24(3), 7-22. http://dx.doi.org/10.1016/S0090-2616(96)90002-9.

Comité Européen de Normalisation. (2018). European ICT professional role profiles - Part 1: 30 ICT profiles. (CEN Workshop Agreement). Brussels: CEN.

Conselho Federal de Engenharia e Agronomia. (1973, Junho 29). Discrimina atividades das diferentes modalidades profissionais da Engenharia, Arquitetura e Agronomia (Resolução no. 218, de 29 de junho de 1973. Diário Oficial da República Federativa do Brasil. Retrieved in 26 November 2019, from http://normativos.confea.org.br/ementas/visualiza.asp?idEmenta=266

Conselho Federal de Engenharia e Agronomia. (1975, Outubro 9). Discrimina as atividades profissionais do Engenheiro de Produção (Resolução $n^{\circ}$ 235, de 9 de Outubro de 1975). Diário Oficial da República Federativa do Brasil. Retrieved in 26 November 2019,, from http://normativos.confea.org.br/downloads/0235-75.pdf

Debortoli, S., Müller, 0., \& vom Brocke, J. (2014). Comparing business intelligence and big data skills: a text mining study job advertisements. Business \& Information Systems Engineering, 6(5), 289-300. http://dx.doi.org/10.1007/s12599-014-0344-2.

Ding, Y., Jin, Y., Ren, L., \& Hao, K. (2013). An intelligent self-organization scheme for the internet of things. IEEE Computational Intelligence Magazine, 8(3), 41-53. http://dx.doi.org/10.1109/MCl.2013.2264251.

Dyer, J. H., \& Singh, H. (1998). The relational view: cooperative strategy and sources of interorganizational competitive advantage. Academy of Management Review, 23(4), 660-679. http://dx.doi.org/10.5465/amr.1998.1255632.

Englund, R. L., \& Highlights, A. B. (2012). The complete project manager: building the right set of skills for greater project success. In $P M I$ Global Congress 2012. Marsailles, France: Project Management Institute. Retrieved in 26 November 2019, from www.englundpmc.com

Freddi, D. (2018). Digitalisation and employment in manufacturing. Al \& Society, 33(3), 393-403. http://dx.doi.org/10.1007/s00146017-0740-5.

Frey, C. B., \& Osborne, M. A. (2013). The Future of Employment: How Susceptible are Jobs to Computerisation? Technological Forecasting and Social Change, 114(1), 254-280. http://dx.doi.org/10.1016/j.techfore.2016.08.019. 
Ghobakhloo, M. (2018). The future of manufacturing industry: a strategic roadmap toward Industry 4.0. Journal of Manufacturing Technology Management, 29(6), 910-936. http://dx.doi.org/10.1108/JMTM-02-2018-0057.

Graczyk-Kucharska, M., Szafranski, M., Golinski, M., Spychala, M., \& Borsekova, K. (2018). Model of competency management in the network of production enterprises in industry 4.0 - Assumptions. Lecture Notes in Mechanical Engineering, (201519), $195-204$. http://dx.doi.org/10.1007/978-3-319-68619-6_19.

Harari, Y. N. (2017, 8 May). The meaning of life in a world without work. The Guardian, p. 4. Retrieved in 26 November 2019 , from https://www.theguardian.com/technology/2017/may/08/virtual-reality-religionrobots-sapiens-book.

Ilvonen, l., Thalmann, S., Manhart, M., \& Sillaber, C. (2018). Reconciling digital transformation and knowledge protection: A research agenda. Knowledge Management Research and Practice, 16(2), 235-244. http://dx.doi.org/10.1080/14778238.2018.1445427.

Lima, R. M., Mesquita, D., Rocha, C., \& Rabelo, M. (2017). Defining the industrial and engineering management professional profile: A longitudinal study based on job advertisements. Production, 27(spe.), 27. http://dx.doi.org/10.1590/0103-6513.229916.

Longo, F., Nicoletti, L., \& Padovano, A. (2017). Smart operators in industry 4.0: A human-centered approach to enhance operators' capabilities and competencies within the new smart factory context. Computers \& Industrial Engineering, 113, 144-159. http:// dx.doi.org/10.1016/j.cie.2017.09.016.

Murawski, M., \& Bick, M. (2017). Digital competences of the workforce - A research topic? Business Process Management Journal, 23(3), 721-734. http://dx.doi.org/10.1108/BPMJ-06-2016-0126.

Nordhaug, 0., \& Grenhaug, K. (1994). Competences as resources in firms. International Journal of Human Resource Management. http://dx.doi.org/10.1080/09585199400000005.

Organisation for Economic Co-operation and Development. (2016). Stimulating digital innovation for growth and inclusiveness the role of policies for the successful diffusion of ICT 2016 Ministerial Meeting on the Digital Economy background. Report. Paris: OECD.

Organisation for Economic Co-operation and Development. (2018). Rethinking quality assurance for higher education in Brazil. Paris: OECD. Retrieved in 26 November 2019, from https://doi.org/https://doi.org/10.1787/9789264309050-en

Rouvrais, S., Ormrod, J., Landrac, G., Mallet, J., Gilliot, J. M., Thépaut, A., \& Tremenbert, P. (2006). A mixed project-based learning framework: preparing and developing student competencies in a French Grande Ecole. European Journal of Engineering Education, 31(1), 83-93. http://dx.doi.org/10.1080/03043790500429500.

Santos, P. F., Simon, A. T., Guimarães, G. E., Amorim, M., \& Vieira Junior, M. (2017). Analyzing the competences of production engineering graduates: an industry perspective. Production, 27(0). http://dx.doi.org/10.1590/0103-6513.005317.

Shamim, S., Cang, S., Yu, H., \& Li, Y. (2016). Management approaches for Industry 4.0: A human resource management perspective. 2016 IEEE Congress on Evolutionary Computation, CEC 2016, (October 2017), 5309-5316. http://dx.doi.org/10.1109/CEC.2016.7748365

Shamim, S., Cang, S., Yu, H., \& Li, Y. (2017). Examining the feasibilities of Industry 4.0 for the hospitality sector with the lens of management practice. Energies, 10(4), 499. http://dx.doi.org/10.3390/en10040499.

Teece, D. J., Pisano, G., \& Shuen, A. (1997). Dynamic capabilities and strategic management. Strategic Management Journal, 18(March), 509-533. http://dx.doi.org/10.1002/(SICI) 1097-0266(199708)18:7<509::AID-SMJ882>3.0.C0;2-Z.

Trilling, B., \& Fadel, C. (2009). 21st Century Skills: Learning for life in our times. San Francisco, CA: Jossey-Bass.

Uzzi, B. (1997). Social structure and competition in interfirm networks: The paradox of embeddedness. Administrative Science Quarterly, 42(2), 35-67. http://dx.doi.org/10.2307/2393808.

Vieru, D., Bourdeau, S., Bernier, A., \& Yapo, S. (2015, January 5-8). Digital competence: A multidimensional conceptualization and a typology in an SME context. Proceedings of the Annual Hawaii International Conference on System Sciences, 2015 (pp. 4681-4690). Kauai, Hl: IEEE. http://dx.doi.org/10.1109/HICSS.2015.557

World Economic Forum. (2018). The Future of Jobs Report: Centre for the new economy and society. Geneva, Switzerland: WEF. Retrieved in 26 November 2019, from https://www.weforum.org/reports/the-future-of-jobs-report-2018.

Xu, L. D., He, W., \& Li, S. (2014). Internet of things in industries: A survey. IEEE Transactions on Industrial Informatics, 10(4), 22332243. http://dx.doi.org/10.1109/Tll.2014.2300753.

Yanaze, L. K. H., \& Lopes, R. D. (2015, February 19). Transversal competencies of electrical and computing engineers considering market demand. In: Proceedings - Frontiers in Education Conference, FIE. Madrid, Spain: IEEE. https://doi.org/10.1109/FIE.2014.7044169 